\title{
BMJ Open Presenting a strong and united front to tobacco industry interference : a content analysis of Australian newspaper coverage of tobacco plain packaging 2008-2014
}

Caroline Louise Miller, ${ }^{1,2}$ Aimee Lee Brownbill, ${ }^{1,2}$ Joanne Dono, $^{2}$ Kerry Ettridge ${ }^{2}$

To cite: Miller CL, Brownbill AL, Dono J, et al. Presenting a strong and united front to tobacco industry interference : a content analysis of Australian newspaper coverage of tobacco plain packaging 2008-2014. BMJ Open 2018;8:e023485. doi:10.1136/ bmjopen-2018-023485

- Prepublication history for this paper is available online. To view these files, please visit the journal online (http://dx.doi org/10.1136/bmjopen-2018023485).

Received 12 April 2018 Revised 23 July 2018 Accepted 22 August 2018

\section{Check for updates}

(c) Author(s) (or their employer(s)) 2018. Re-use permitted under CC BY-NC. No commercial re-use. See rights and permissions. Published by BMJ.

${ }^{1}$ School of Public Health, University of Adelaide, Adelaide, South Australia, Australia

${ }^{2}$ Population Health Research Group, SAHMRI, Adelaide, South Australia, Australia

Correspondence to Dr Caroline Louise Miller; caroline.miller@sahmri.com

\section{ABSTRACT}

Objectives In 2012, Australia was the first country in the world to introduce plain or standardised tobacco packaging, coupled with larger graphic health warnings. This policy was fiercely opposed by industry. Media coverage can be an influential contributor to public debate, and both public health advocates and industry sought media coverage for their positions. The aim of this study was to measure the print media coverage of Australian's plain packaging laws, from inception to roll-out, in major Australian newspapers.

Methods This study monitored mainstream Australian print media (17 newspapers) coverage of the plain packaging policy debate and implementation, over a 7-year period from January 2008 to December 2014. Articles $(n=701)$ were coded for article type, opinion slant and topic(s).

Design Content analysis.

Results Coverage of plain packaging was low during preimplementation phase (2008-2009), increasing sharply in the lead into legislative processes and diminished substantially after implementation. Articles covered policy rationale, policy progress and industry arguments. Of the news articles, $96 \%$ were neutrally framed. Of the editorials, $55 \%$ were supportive, $28 \%$ were opposing, $12 \%$ were neutral and $5 \%$ were mixed.

Conclusions Protracted political debate, reflected in the media, led to an implementation delay of plain packaging. While Australian media provided comprehensive coverage of industry arguments, news coverage was largely neutral, whereas editorials were mostly supportive or neutral of the policy. Countries seeking to implement plain packaging of tobacco should not be deterred by the volume of news coverage, but should actively promote the evidence for plain packaging in the media to counteract the arguments of the tobacco industry.

\section{INTRODUCTION}

Australia has led the world in introducing plain or standardised packaging of all tobacco products. Plain packaging came into effect on 1 December 2012. ${ }^{12}$ The implementation was preceded by years of policy preparation, and
Strengths and limitations of this study

- This content analysis provides detailed and comprehensive coverage of newspaper articles published preimplementation and postimplementation of the world-first tobacco plain packaging initiative in Australia.

- The observational design allowed us to monitor the contribution of industry arguments which continue to be recycled around the globe, to the fierce and protracted policy debate played out in Australia's print media.

- Study results are limited to newspaper articles and therefore do not capture other sources of media influence (eg, advertising).

intense lobbying by public health advocates and by industry against the globally unprecedented reforms. The passing of legislation was followed by multiple, unsuccessful legal challenges by industry. Several countries have since followed suit and are now in the process of debating, legislating and implementing plain tobacco packaging. ${ }^{3}$ These jurisdictions routinely face industry opposition similar to that which occurred in Australia. ${ }^{5}$

Media play an important role in public policy debate. ${ }^{67}$ Both industry and health advocates seek media coverage on matters of public health policy, understanding its role in influencing and reflecting public opinion and political decision-makers. The agenda setting function of the media is well established. ${ }^{8}$ The amount of media coverage can signal the importance of an issue and contribute to guiding the public's response. ${ }^{9}{ }^{10}$ Furthermore, media content can shape public discourse by how the issue is framed, that is, how the issue is presented to give salience to one aspect over others in order to give meaning to the audience. ${ }^{11}$ Studies across 
multiple jurisdictions have shown that tobacco policy frequently features in news coverage ${ }^{612-14}$ and that such coverage can influence public perceptions ${ }^{15}{ }^{16}$ as well as policy and behaviour change. ${ }^{12} 1718$ Tobacco control coverage is often cast favourably. ${ }^{612-1419-21}$ Yet, the tobacco industry has used the media to thwart policy progression by reframing the health issue as an economic, commercial or political issue..$^{22} 23$ The media use controversy to sell newspapers, and so coverage can take on the voice of the dominant stakeholder rather than the scientific evidence. ${ }^{24}{ }^{25}$ Furthermore, the ideological and financial positioning of a newspaper can influence editorial decisions on what to publish. ${ }^{26}$

Newspaper, television and radio were central in Australian debate of plain packaging, as they were for previous policy reforms such as smoke-free policies, ${ }^{24}$ 27-31 tax initiatives, ${ }^{32} 33$ point-of-sale reforms ${ }^{34}$ and graphic health warnings. ${ }^{35}$ The media also has a role in how current tobacco control issues are portrayed, such as those relating to illicit trade ${ }^{1536}$ and electronic cigarettes. ${ }^{37}$ With regard to plain packaging, one New Zealand study ${ }^{38}$ explored the rhetoric used by the tobacco industry in a mass media advertising campaign designed to sway public opinion against the adoption of plain packaging. They found that common tactics included logical fallacies and unsound arguments. In an examination of online comments posted in response to news articles reporting on the announcement of the plain packaging initiative in 2010, Freeman ${ }^{23}$ found that the prevailing argument opposing the initiative was the same as that used in a mass media campaign funded by the tobacco industry. These analyses of tobacco control-related news articles demonstrate the importance of public health advocacy in counteracting the arguments put forward by the tobacco industry. Furthermore, Australian tobacco control advocacy groups have a history of contributing to the news discourse and shaping policy development. ${ }^{22} 2539$ Nevertheless, the campaign against plain packaging was prolonged and intense. In addition to unpaid public relations efforts, industry took out multiple full-page advertisements in Australia's major newspapers, as did Australian health agencies, although in far less volume. ${ }^{40}$

This study aimed to document the volume and content of the print media coverage in major Australian newspapers of Australian's plain packaging laws; from inception to roll-out. The observations start in January 2008, the year in which the Australian Government established the National Preventive Health Taskforce, whose draft (October 2008) and final reports (September 2009) recommended plain packaging. ${ }^{41}$ On 29 April 2010, the prime minister announced that Australia would adopt plain packaging. ${ }^{42}$ A general election was held in August 2010. After draft regulations were released in April 2011, protracted parliamentary debate occurred which led to an announcement (2 November 2011) by the minister for health that implementation would be delayed. The legislation passed on 1 December 2011; coming into effect on 1 December $2012 .^{43}$ The observations in this study conclude 2 years postimplementation in December 2014.

\section{METHODS}

Newspaper articles published between 1 January 2008 and 1 December 2014 were sourced from all major Australian daily and weekend print newspapers through the Australian/New Zealand Reference Centre and Factiva online database, both of which contain full-text articles. The major (ie, most read) newspapers of each state/territory were selected, and a minimum of 100000 readership was required in those states having multiple major newspapers. ${ }^{44}$ This included two national newspapers, 10 daily and five weekend state newspapers. Articles were searched using the following terms: plain, pack*, tobacco, cigarette and smok*; the default search settings for both databases were used (ie, Australian/New Zealand Reference Centre: title, keywords, description; Factiva: full-text) and a 'print media only' filter was applied. The search produced 2147 articles which were screened for duplicates $(n=482$, articles duplicated in newspapers across multiple editions) and against exclusion criteria $(n=964)$ of: less than five lines long $(\mathrm{n}=74)$, not relevant to plain packaging $(\mathrm{n}=778)$ and inappropriate article type ( $\mathrm{n}=112$; eg, cartoon), yielding 701 separate articles for analysis. Coding was based on previous studies ${ }^{645}$ with minor amendments to account for the use of online databases rather than hard-copy newspaper clippings. The coding of prominence was also modified because imagery accompanying an article was used to define prominence in previous studies whereas imagery was not available from the online databases used in this study. Prominence was coded as very high: page 1, high: pages $2-5$ or low: page 6 onwards. Articles were coded by type: news (factual account of issues or events); editorial (opinion of newspaper or columnist); letters/ comments (letters to the editor and readers' comments sections; included for comprehensiveness of coverage but excluded from analysis as they did not contain sufficient detail), and for opinion slant which focused on the dominant view which was expressed by the author and was coded as either supporting, opposing, neutral (ie, author expressed no opinion) or mixed (ie, author expressed both supporting and opposing opinions) towards plain packaging. One author coded all articles. A second researcher recoded a randomly selected $10 \%$ of articles. The Kappa score was 0.94 .

\section{Patient and public involvement}

Neither patients nor the public were involved in this study.

\section{RESULTS}

\section{Volume and type of articles}

During the observation period, plain packaging was mentioned in 701 articles (558 news articles (79.6\%), 100 editorials $(14.3 \%)$ and 43 letters/comments $(6.1 \%$; 39 letters and 4 groups of comments). The majority of articles were low prominence $(70.0 \%)$, with $25.7 \%$ high prominence and $4.3 \%$ very high prominence. As depicted in figure 1, print media coverage was prevalent at the times of: the announcement of intention to adopt 
plain packaging, the Australian general election which coincided with paid advertising by industry and health groups $^{40}$ and release of the draft bill for consultation through to the eventual passage of legislation. Coverage spiked again during the legal challenge in Australia's high court (April 2012), and on announcement that the industry's legal case had failed (August 2012). Smaller peaks were observed around actual implementation and in June 2013, in response to Britain's discontinuation of plain packaging laws and the release of some Australian data on impact.

\section{Opinion slant}

News articles were overwhelmingly neutral (96.1\%). Of the editorials, $55.0 \%$ were supporting, $28.0 \%$ were opposing, $12.0 \%$ were neutral and $5.0 \%$ were mixed. Among letters/comments, $37.2 \%$ were supporting, $16.3 \%$ were opposing, $44.2 \%$ were mixed and $2.3 \%$ were neutral.

\section{Relationship between article type, prominence and opinion slant}

Of the $30(4.3 \%)$ articles achieving very high prominence, two were supporting plain packaging (one news article, one editorial) and the remainder were neutral news articles. The two supporting articles achieving front page coverage were both published in 2012, the first article (editorial) in January following the passing of plain packaging legislation and the second article (news) in August following the industry legal case failure. The majority of high-prominence articles were also neutral (169 out of $180)$; however, there were nine articles supporting plain packaging (four editorials, three news articles and two letters) and two editorials opposing plain packaging. Both opposing editorials were published on 18 June 2014 in The Australian (national daily newspaper), in response to the critique of the industry released report on cigarette sales volume since plain packaging. A supporting editorial was also published during this period (24 June 2014; The Canberra Times). All of the remaining high prominence articles were published prior to implementation. Two articles (one news, one editorial), published in September 2010 , were critiques of the 'It won't work ${ }^{40}$ mass media and public relations campaign funded by the tobacco industry. An editorial was published in May 2011, coinciding with the prolific reporting of the draft bill consultation. Two articles (one news, one editorial), published in April 2012, were reporting on the tobacco industry's high court challenge, and a news article published in August 2012, reported on the failure of this challenge.

\section{Content of articles}

Article content routinely covered multiple elements of plain packaging. Articles featured updates on progress of the policy (policy announcements, consultations, legislative process, implementation, legal challenges and their outcomes). The rationale for plain packaging as a tobacco control initiative and the harms of smoking to health were also routinely covered.
Tobacco industry's objections and arguments were covered, including: 'nanny state' objections; predictions that the policy 'wouldn't work'; predictions of unintended consequences including smuggling and illicit trade, youth smoking, harm to small business; as well as legal arguments about acquisition of intellectual property.

While industry arguments received widespread coverage, there was also coverage of critique of industry data and arguments, even from newspapers that were traditionally antiregulation (see the following examples).

The tobacco industry warned yesterday plain packaging could see the price of cigarettes halve over time, because generic packets would only benefit counterfeiters and smugglers. "When all cigarette packs look the same and lose their trademarks and distinguishing features, counterfeiters will have a field day mass producing packets to smuggle into Australia," said David Crow, chief executive of British American Tobacco. The Age, 18/05/2011, p6; News

Imperial says anecdotal evidence shows illicit trade has increased since plain packaging. But Australian Customs and Border Protection says tobacco seizure data since the new laws were introduced 'does not support tobacco industry claims that plain packaging would result in a big spike in illegal tobacco imports'. The Age, 10/10/2013, p22; News

This newspaper favours the use of market mechanisms to achieve policy outcomes rather than the imposition of regulations that restrict the use of private property. While the government does have a legitimate interest in public health, individuals also have a right to decide their tobacco use... However, Australia has had some big wins in improving public health through regulation... Given that there is no safe way to consume tobacco products, and that smoking-related expenses are at least $\$ 12$ billion a year, taxes would have to double to cover the cost of health problems tobacco creates. In that situation, the plain-packaging laws may be a necessary evil. The Australian Financial Review, 17/08/2012, p42; Editorial

Industry calls for delays in implementation were covered in the media. For example, industry argued there would be supply issues as the proposed implementation timeline was too tight. The July 2012 deadline was subsequently extended to December 2012.

SMOKERS face the prospect of being unable to purchase their preferred brand of cigarettes when plain packaging is introduced, with the tobacco industry warning it will not be able to supply the olive-green packs by next year's July 1 deadline. The Australian, 5/08/2011, p6; News

Industry tactics featured in a wave of stories, following a television investigative journalism piece about industry funding of a 'front-organisation'. 
Senator Siewert recalled that the international tobacco companies spent $\$ 5$ million during the election campaign "'using a front organisation the Alliance of Australian Retailers in an attempt to prevent the introduction of plain packaging laws"'. The Canberra Times, 20/11/2010, p15; News

The likely effectiveness of plain packaging was a major source of debate, as was the need to stand up to industry to pursue tobacco control policy for health.

Let there be no mistake, big tobacco is fighting the government for one very simple reason - because it knows, as we do, that plain packaging will work,' Ms Roxon [then Australian Attorney General] said. The Age, 22/12/2011, p1; News

Globally, we need to present a strong and united front to tobacco industry interference so we can finally end the pain, illness, suffering and costs caused by tobacco. Herald Sun, 28/05/2012, p23; Editorial

\section{DISCUSSION}

Media coverage of Australia's plain packaging was extensive and reflected the protracted political debate, delays in implementation and legal challenges. Plain packaging saw the tobacco industry step into the media in a way that had not been seen in Australia for many years. Media coverage provided comprehensive coverage of industry arguments, but it also covered critiques of industry's data, industry's arguments and practices. Prior to the passing of the plain packaging bill, the media were covering a public health policy debate. Postlegislation, the media were covering the litigation as it unfolded, and the uncertainty of outcome that involved. Despite the apparent volume, much of the coverage was of low prominence, neutral and interest largely dissipated on implementation. When an opinion was present, there were more articles that were supportive than opposing plain packaging.

The volume of articles peaked following the release of the draft Tobacco Plain Packaging Bill 2011 and consultation paper for public comment (7 April 2011). By the closing date (6 June 2011), the government had received 265 submissions, of which 99 supported the bill and 158 opposed. ${ }^{46}$ The arguments raised in the public consultation reflected those reported in the media; propolicy arguments centred on health and social benefits, backed up by scientific evidence, whereas antipolicy arguments were more varied and included the 'it won't work' rhetoric, economic impact on businesses, increase in illicit trade and infringements on consumer rights. Both sides of the argument were often discussed within the same article.

Recent research on industry responses to plain packaging proposals in other jurisdictions have demonstrated that claims used in Australia, such as increased illicit trade and negative economic consequences, are being recycled despite evidence clearly demonstrating the falsehood of such claims. ${ }^{584748}$ One study identified 173 arguments against plain packaging in tobacco industry documents submitted during a plain packaging consultation process in the UK. ${ }^{48}$ These tactics serve to overwhelm and to delay policy adoption and implementation, but do not hold up to scrutiny when challenged. ${ }^{4}$ Lessons learnt from Australia allowed the Canadian Government to combat this strategy during the consultation process by requiring that all submissions declare potential conflicts of interest and substantiate arguments with peer-reviewed evidence. ${ }^{49}$ While these arguments continue to be perpetuated through the media, plain packaging laws have since been passed in the UK, Ireland, New Zealand, Canada and France, with more likely to follow.

The second largest peak in articles corresponded with the High Court of Australia's rejection of the constitutional challenge to plain packaging legislation made by four tobacco companies (15 August 2012). This gave the green light for plain packaging to be implemented as planned. Relatively few articles were published once plain packaging was implemented. However, coverage of plain packaging increased again in June 2014 which corresponded with industry research claiming that plain packaging had failed. This news was reported in overseas newspapers but was quickly discredited in Australia with the use of a growing body of evidence demonstrating that plain packaging was effective. ${ }^{50}$

Nevertheless, the tobacco industry's use of misleading and unsubstantiated reports to generate negative media interest needs to be addressed. Recent research on the media reporting on illicit tobacco trade in the $\mathrm{UK}^{15}$ and Canada ${ }^{36}$ showed that industry continues to actively undermine public policy. They conclude that journalists need to scrutinise data sources more critically and hold tobacco industry reports to account by subjecting their data to independent peer review. However, the tobacco industry is aware of the high level of public distrust it attracts, and solicits other third-party organisations to disseminate its arguments, ${ }^{51}$ and these organisations are not always forthcoming in declaring financial relationships with the tobacco industry. ${ }^{52}$ In Australia, advocacy is core business for non-government public health bodies, with resources dedicated to maintaining contact with policy-makers, critically reviewing published documents, producing evidence-based reports, issuing press releases and holding press conferences, and employing dedicated media and public relations staff to proactively (generate newsworthy story) and reactively (respond to journalists' request for comment on a story) give voice to tobacco control issues. ${ }^{25}$ Advocacy has been critical in shaping tobacco control news coverage for many years, and this experience is likely to have been essential in producing the timely and newsworthy proplain packaging press releases that were reported in the media. ${ }^{25}$ This was facilitated by having evidence of bipartisan and community support for the policy. ${ }^{40}$

It is important to note that policy implementation was delayed, and industry tactics did receive a high volume 
of coverage, although mostly neutral in tone. The power structure of the media may contribute to the stance that is taken on whether the dominant viewpoint aligns with industry or public health, ${ }^{26}$ but such analysis was beyond the scope of this study. By reporting tobacco industry tactics and misinformation, the media are complicit in biasing the narrative around policy initiatives, even if they also report alternative perspectives put forward by health advocates. However, reports on tobacco industry tactics, such as policy setbacks, may help consolidate the negative view of the industry by sophisticated audiences who already view such tactics as unethical. ${ }^{19}$ Thus, ongoing advocacy efforts to keep tobacco issues in the news beyond topical policy debates is essential for maintaining an educated and protobacco control audience ready for when industry strikes again. ${ }^{19} 2539$

This study focused on newspaper articles and did not include other sources of media influence (eg, advertising). It may have missed articles not contained within the database. The findings are specific to plain packaging and may not generalise to media coverage of public health policy debates outside of tobacco control. Nevertheless, this study demonstrates how large volumes of industry misinformation can be challenged and thwarted using evidence-based public health advocacy. Countries seeking to implement plain packaging of tobacco should not be deterred by the volume of news coverage of plain packaging debates or coverage of industry counter-arguments, but should be actively promoting the policy rationale and evidence for plain packaging in the media to counteract the response of the tobacco industry.

Contributors CLM and KE conceptualised the study. KE and ALB designed the study with input from CLM and JD. ALB collected and analysed the data and all authors contributed to interpretation of the results. CLM drafted the manuscript which was critically reviewed by all authors. The final version was approved by all authors.

Funding The authors have not declared a specific grant for this research from any funding agency in the public, commercial or not-for-profit sectors.

Competing interests None declared.

Patient consent Not required.

Provenance and peer review Not commissioned; externally peer reviewed.

Data sharing statement The dataset analysed during the current study is available from the corresponding author on reasonable request.

Open access This is an open access article distributed in accordance with the Creative Commons Attribution Non Commercial (CC BY-NC 4.0) license, which permits others to distribute, remix, adapt, build upon this work non-commercially, and license their derivative works on different terms, provided the original work is properly cited, appropriate credit is given, any changes made indicated, and the use is non-commercial. See: $\mathrm{http}: / /$ creativecommons.org/licenses/by-nc/4.0/.

\section{REFERENCES}

1. Australian Government Federal Register of Legislation. Tobacco Plain Packaging Act 2011. 2011 www.comlaw.gov.au/details/c2011a00148 (accessed 26 Mar 2018).

2. Scollo M, Lindorff K, Coomber K, et al. Standardised packaging and new enlarged graphic health warnings for tobacco products in Australia-legislative requirements and implementation of the Tobacco Plain Packaging Act 2011 and the Competition and Consumer (Tobacco) Information Standard, 2011. Tob Control 2015;24(Suppl 2):ii9-ii16.
3. Murphy J. Australia's WTO plain cigarette packaging case: an update. Canberra: Parliament of Australia, 2014. www.aph.gov. au/About_Parliament/Parliamentary_Departments/Parliamentary_ Library/FlagPost/2014/July/WTO_plain_cigarette_packaging_case. (accessed 26 Mar 2018).

4. World Health Organization. Plain packaging of tobacco products: evidence, design and implementation. Geneva: World Health Organization, 2016;86:www.who.int/tobacco/publications/industry/ plain-packaging-tobacco-products/en/. (accessed 23 Jul 2018).

5. Daube M, Eastwood P, Mishima M, et al. Tobacco plain packaging: the Australian experience. Respirology 2015;20:1001-3.

6. Wakefield MA, Brennan E, Durkin SJ, et al. Still a burning issue: trends in the volume, content and population reach of newspaper coverage about tobacco issues. Crit Public Health 2011;21:313-25.

7. Dunlop SM, Cotter T, Perez D, et al. Tobacco in the news: associations between news coverage, news recall and smokingrelated outcomes in a sample of Australian smokers and recent quitters. Health Educ Res 2012;27:160-71.

8. McCombs ME, Shaw DL. The agenda-setting function of mass media. Public Opin Q 1972;36:176-87.

9. Wallack L, Dorfman L. Media advocacy: a strategy for advancing policy and promoting health. Health Educ Q 1996;23:293-317.

10. McCombs ME, Shaw DL. The evolution of agenda-setting research: Twenty-five years in the marketplace of ideas. J Commun 1993;43:58-67.

11. Entman RM. Framing: Toward clarification of a fractured paradigm. J Commun 1993;43:51-8.

12. Smith KC, Terry-McElrath $\mathrm{Y}$, Wakefield $\mathrm{M}$, et al. Media advocacy and newspaper coverage of tobacco issues: a comparative analysis of 1 year's print news in the United States and Australia. Nicotine Tob Res 2005;7:289-99.

13. He S, Shen Q, Yin X, et al. Newspaper coverage of tobacco issues: an analysis of print news in Chinese cities, 2008-2011. Tob Control 2014;23:345-52.

14. McGee R, Bang S, Marsh L. Newspaper coverage of tobacco control in New Zealand. Aust N Z J Public Health 2014;38:265-9.

15. Rowell A, Evans-Reeves K, Gilmore AB. Tobacco industry manipulation of data on and press coverage of the illicit tobacco trade in the UK. Tob Control 2014;23-e35-e43.

16. Menashe CL, Siegel M. The power of a frame: an analysis of newspaper coverage of tobacco issues-United States, 1985-1996. $J$ Health Commun 1998;3:307-25.

17. Niederdeppe J, Farrelly MC, Thomas KY, et al. Newspaper coverage as indirect effects of a health communication intervention: the florida tobacco control program and youth smoking. Communication Research 2007;34:382-405.

18. Davis RM, Gilpin EA, Loken B, et al. The role of the media in promoting and reducing tobacco use:In. NCl Tobacco Control Monograph Series No.19 (NIH Publication. No 07-6242.200). Bethesda: MD: US Department of Health and Human Services, 2008.

19. Durrant R, Wakefield M, McLeod K, et al. Tobacco in the news: an analysis of newspaper coverage of tobacco issues in Australia, 2001. Tob Control 2003;12 Suppl 2(suppl 2):75ii-81.

20. Long M, Slater MD, Lysengen L. US news media coverage of tobacco control issues. Tob Control 2006;15:367-72.

21. Stillman FA, Cronin KA, Evans WD, et al. Can media advocacy influence newspaper coverage of tobacco: measuring the effectiveness of the American stop smoking intervention study's (ASSIST) media advocacy strategies. Tob Control 2001;10:137-44.

22. Champion D, Chapman S. Framing pub smoking bans: an analysis of Australian print news media coverage, March 1996-March 2003. $J$ Epidemiol Community Health 2005;59:679-84.

23. Freeman B. Tobacco plain packaging legislation: a content analysis of commentary posted on Australian online news. Tob Control 2011;20:361-6.

24. Thrasher JF, Kim SH, Rose I, et al. Media coverage of smoke-free policies after their innovation. J Health Commun 2015;20:297-305.

25. Wakefield MA, Brennan E, Durkin SJ, et al. Making news: the appearance of tobacco control organizations in newspaper coverage of tobacco control issues. Am J Health Promot 2012;26:166-71.

26. Mercille J. Media coverage of alcohol issues: A critical political economy framework-a case study from ireland. Int $J$ Environ Res Public Health 2017;14:650.

27. Wackowski OA, Lewis MJ, Hrywna M. Banning smoking in New Jersey casinos-a content analysis of the debate in print media. Subst Use Misuse 2011;46:882-8.

28. Fahy D, Trench B, Clancy L. Communicating contentious health policy: lessons from Ireland's workplace smoking ban. Health Promot Pract 2012;13:331-8. 
29. Kenterelidou C. Framing public health issues: the case of smoking ban in Greece, public health policy framing equals healthy framing of public policy? J Health Commun 2012;5:116-28

30. Moshrefzadeh A, Rice W, Pederson A, et al. A content analysis of media coverage of the introduction of a smoke-free bylaw in Vancouver parks and beaches. Int J Environ Res Public Health 2013;10:4444-53.

31. McDaniel PA, Offen N, Yerger V, et al. "Tired of watching customers walk out the door because of the smoke": a content analysis of media coverage of voluntarily smokefree restaurants and bars. $B M C$ Public Health 2015;15:761.

32. Harris JK, Shelton SC, Moreland-Russell S, et al. Tobacco coverage in print media: the use of timing and themes by tobacco control supporters and opposition before a failed tobacco tax initiative. Tob Control 2010;19:37-43.

33. Thrasher JF, Kim SH, Rose I, et al. Print media coverage around failed and successful tobacco tax initiatives: the South Carolina experience. Am J Health Promot 2014;29:29-36.

34. Myers AE, Southwell BG, Ribisl KM, et al. Setting the agenda for a healthy retail environment: content analysis of US newspaper coverage of tobacco control policies affecting the point of sale, 2007-2014. Tob Control 2017;26:406-14.

35. Miller CL, Hill DJ, Quester PG, et al. Response of mass media, tobacco industry and smokers to the introduction of graphic cigarette pack warnings in Australia. Eur J Public Health 2009;19:644-9.

36. Smith J, Thompson S, Lee K. Death and Taxes: the framing of the causes and policy responses to the illicit tobacco trade in Canadian newspapers. Cogent Soc Sci 2017;3:1325054.

37. Yates K, Friedman K, Slater MD, et al. A Content Analysis of Electronic Cigarette Portrayal in Newspapers. Tob Regul Sci 2015;1:94-102.

38. Waa AM, Hoek J, Edwards R, et al. Analysis of the logic and framing of a tobacco industry campaign opposing standardised packaging legislation in New Zealand. Tob Control 2017;26:629-33.

39. MacKenzie R, Chapman S. Generating news media interest in tobacco control; challenges in an advanced policy environment. Health Promot J Austr 2012;23:92-6.

40. Scollo MM, Freeman B, Greenhalg EM. 11.10 Packaging as promotion: evidence for and effects of plain packaging. In: Scollo MM, Winstanley MH, eds. Tobacco in Australia: Facts and issues. Melbourne: Cancer Council Victoria, 2016. updated Sep 2017. www. tobaccoinaustralia.org.au/chapter-11-advertising/11-10-packagingas-promotion. (accessed 23 Mar 2018).

41. National Preventative Health Taskforce. Australia: The healthiest country by 2020: In. A discussion paper prepared by the National Preventative Health Taskforce. Canberra: Australian Government, 2018. http://webarchive.nla.gov.au/gov/20160923060416/http:// www.preventativehealth.org.au/internet/preventativehealth/ publishing.nsf/Content/discussion-healthiest. (accessed $23 \mathrm{Jul}$ 2018).

42. Cancer Council. Timeline, international developments \& major news stories. www.cancervic.org.au/plainfacts/browse.asp?ContainerlD= timelineandinternationaldevelopments (accessed 26 Mar 2018).

43. Australian Government Department of Health, 2014. Introduction of tobacco plain packaging in Australia. updated 23 Oct 2017 www. health.gov.au/internet/main/publishing.nsf/Content/tobacco-plain (accessed 26 Mar 2018).

44. Morgan R. Australian Newspaper Readership. 2014 http://www. roymorgan.com/industries/media/readership/newspaper-readership (accessed 22 Aug 2014).

45. Clegg Smith K, Wakefield M, Siebel C, et al. Coding the news: the development of a methodological framework for coding and anlyzing newspaper coverage of tobacco issues. ImpacTeen Research Paper Series 2002;21.

46 Australian Government Department of Health and Ageing. Public consultation on plain packaging of cigarettes: National Library of Australia. 2011 http://webarchive.nla.gov.au/gov/20140215002600/ http://www.health.gov.au/internet/yourhealth/publishing.nsf/Content/ plainpack-tobacco (accessed 23 Jul 2018).

47 Ulucanlar S, Fooks GJ, Hatchard JL, et al. Representation and misrepresentation of scientific evidence in contemporary tobacco regulation: a review of tobacco industry submissions to the UK Government consultation on standardised packaging. PLoS Med 2014;11:e1001629.

48 Jly L, Fooks G, de Vries NK, et al. Can't see the woods for the trees: exploring the range and connection of tobacco industry argumentation in the 2012 UK standardised packaging consultation. Tob Control. 2017:doi: tobaccocontrol-2017.

49 Smith J, Lee K. Protecting the plain packaging consultation from tobacco industry interference. CMAJ 2016;188:E340-E341.

50 Daube M, Chapman S. The Australian's dissembling campaign on tobacco plain packaging. Med J Aust 2014;201:191-2.

51 Vittiglia A, Greenhalgh E. eds. 10A.6 Mechanisms of influencemedia relations. Scollo MM, Winstanley $\mathrm{MH}$, Tobacco in Australia: Facts and issues. Melbourne: Cancer Council Victoria, 2018. www. tobaccoinaustralia.org.au/chapter-10-tobacco-industry/10a-6-themechanisms-of-influence-media-relations. (accessed 23 Jul 2018).

52 Hatchard JL, Fooks GJ, Gilmore AB. Standardised tobacco packaging: a health policy case study of corporate conflict expansion and adaptation. BMJ Open 2016;6:e012634.

53 Barry P. Up in smoke. Adams J, ed. The Australian's exclusive story on plain packaging is just plain wrong: Media Watch: Australian Broadcasting Corporation, 2014. http://www.abc.net.au/mediawatch/ transcripts/s4026465.htm. (accessed 26 Mar 2018). 